\title{
Promoting Indigenous Culture and Community Life in Nigeria Through the Mass Media
}

\author{
Femi Onabajo \\ Department of Mass Communication, University of Lagos, \\ Akoka, Lagos, Nigeria
}

KEYWORDS Cultures; morals; developmental information; belief system

\begin{abstract}
The way and manner the morals and cultures of the typical Nigerian community is promoted depend solely on its mass media. These mass media are responsible for the dissemination of values, ideas, and developmental information in many ways and this goes a long way in elevating cultures and community life. In the Nigerian society, cultures are very important and they are held in great reverence. Culture is the way of life and the belief system of a particular group of people at a particular time. This work aims at re-appraising and reinforcing the significance and value of Nigerian indigenous culture and morals in the framework of their positive contributions to the growth and development of the country in the past and present, as well as their continued relevance to the promotion and preservation of the Nigerian psyche and the role the media can play in ensuring their sustenance.
\end{abstract}

\section{INTRODUCTION}

In this modern day we are surrounded by the mass media. As a result of the explosive growth of the mass media in the recent past, they have become a natural part of life. However, the mass media should not merely be accepted as natural; each person should become aware of how they influence the shaping of his or her own being and the environment in which he or she lives. According to Voelker (1975: 22), the mass media are important forces in our society. They provide information and entertainment and, at the same time, have persuasive powers that are capable of effecting radical changes. For this reason, the role of the mass media in the development and promotion of our culture, moral and community life cannot be overestimated.

Development is the singular ultimate quest of every society. Even the advanced countries still thirst for further development. Essentially, development implies the desire to improve or progress towards improvement in the quality of life of the people or majority of the people in a given society or community. And what happens during development, in essence is that a more active system is created and relations that have been dormant are awakened and parts that have been largely eccentric become interrelated and able to bring about an enormous progress in further activity and productivity. This embraces the social and cultural progress of that society, including those multitudes of different types of changes (in society) from the relatively specific notion of economic expansion to industriali- zation, urbanization, increase in literacy rates and so on.

When therefore, one talks of the role of the media in development, broadly speaking, one is referring to the roles of these media in encouraging people to accept and practice changes in attitudes and behaviour that will bring about development.

Culture could be likened to tradition, which is a belief, principle or way of behaviour which people in a particular society or group have continued to follow for a long time. A culture or tradition seems to exist in a community, perhaps forever, because it is passed on from one generation to another through traditional means of communication. Since cultural beliefs are transferred from the older to the younger generation, there is the temptation to ask how the process of transference will continue when the old and aged become extinct. This is where the issue of communication comes in to ensure that there is a continuous flow of culture from one generation to the next.

Many social changes evident today are at least partially attributable to the mass media. The electronic media in particular provide a global view that has allowed us to become involved in concerns far beyond the scope of earlier generations. Cultural, moral and community opinions have been changed largely by the fact that the mass media can provide seemingly uninterrupted news that have influenced community life, indigenous culture and morals as well. 


\section{RELATING CULTURE TO COMMUNITY LIFE}

Communication and culture reciprocally influence each other. The culture from which individuals come affects the way they communicate and the way individuals communicate can change the culture they share. Culture is about behaviour patterns associated with particular groups of people's way of life. - According to Nida (1954: 25), culture is all learned bahaviour, which is socially acquired, that is the material and non-material traits, which are passed on from one generation to another. People and culture cannot be separated. Culture stands for the aggregate values and concepts which characterize a community. It them follows that people who lack culture or are ignorant of their past experience either written or unwritten are themselves not in full existence. Culture is the product of ecology and is greatly influenced by the environment. Hence it encompasses all the material and nonmaterial expressions of a people, as well as the processes with which these expressions are communicated. These consist of our literature, music, arts, customs, social institutions and other intellectual expressions of the society.

"Culture is the totality of the way of life evolved by a people in their attempts to meet the challenges of living in their environment, which gives order and meaning to their social, economic, aesthetic and religious norms and modes of organization thus distinguishing them as a people from their neighbors" (Harunah, 2000: 32).

Culture comprises material, institutional, philosophical and creative aspects. The material aspect has to do with artifacts in its broadest form (namely: tools, clothing, food, medicine, utensils, housing etc.); the institutional deal with the political, social, legal and economic structures and spiritual objectives; the creative concerns a people's literature (oral and written) as well as their visual and performing arts which are normally molded by as well as help to mould other aspects or culture.

Culture also connotes how we live our lives in relation to our society, that is, our mode of dressing marriage, religion, festivals, child naming, family life etc. and our economy, politics and technology through which a distributive identity of that society is established.

Olaide (2000: 6) submits that what many Nigerians refer to as our culture are traces of achievement of our forefathers at various levels and stages of their development and the cumulative knowledge of these various achievements.

Culture can them be found in our political institutions, our ancient traditions, our literature, our languages and even in our moral values. The moral value of a particular group of people is an embodiment of their culture. Morality varies form place to place. What moves human beings are still their own beliefs, desires and motives. People of the same culture or community are bound to share a common language and also certain moral values. What an individual learns morally, and values he acquires, depend on the culture in which one develops, and the activities and institutions that surround one's life.

The community life of a set of people is based on their culture. Community life is almost the same with culture of the people and this entails activities within the regulation and scope of culture which morality also takes cognizance of. The number and kinds of people in a community have a great influence on type of community/ social living, and this is where the traditions of such people have a great role to play.

Traditions are the customs, practices, bits of legend and folklore and legends go a long way in establishing the community life, that tangible quality which makes it different in spirit from other communities in the same circumstances. Similarly, people in a community share legends and bits of folklore and this common heritage from the past gives people a sense of community solidarity.

Communities are likewise characterized by the things in which they are most interested and their ways of living depend highly on the situations or qualities, or conditions on which they place high value. The way in which a community is organized does much to set the tone of the community and flavor the quality of daily living (Warren 1965: 12).

It is now clear that culture and community life are interwoven and one gives rise to the other. These are the basics used to differentiate a set of people from another. It may now be pertinent to discuss how the mass media have helped to promote them. However the print media will not be considered because of the high illiteracy level prevalent in the country.

\section{THE ROLE OF TELEVISION}

Television as an expensive medium of comm- 
unication has contributed to overall development of the nation in no small measure. When any developing country opts for television, it definitely must be because, among other things, T.V. has an important role to play in advancing the process of national development. It has and is still making a lot of impact on the economic, political, social, cultural and educational advancement of the nation. It is the most effective modern means of mass communication now available to mankind (Akpan, 1988: 13).

The television is regarded as one of the most powerful, if not the most powerful, of the modern media of mass communication. The enormous powers usually ascribed to this medium stems form its audio-visual properties, which command instant believability.

As the most effective modern means of mass communication, its effectiveness in aiding development derives from the following attributes:

(a) T. V. can present things as they really are; (realism achieved through sight and hearing)

(b) Events can be shown as they are happening

(c) It can address the whole person, since its range of subjects is both comprehensive and flexible.

(d) It can also address both the literate and the illiterate with equal success and effectiveness.

(e) It can speak to the individual intimately, but also lends itself to group reception.

(f) It has both intellectual and emotional appeal. As a development agent, television has done much and can do much to activate human intention and cultural development through serious educational programmes which happily are now a feature of Nigerian television.

Learning by television is not limited to schools broadcast; other socio-cultural programmes such as drama pass information across to viewers. The purpose of television plays is partly to impart to the people the moral lessons implied or intended by the plays.

Also, looking at the socio-cultural aspect, television has the ability to activate, socialize, homogenize and even adapt people to their own culture. It also has the ability not only to reflect but also shape opinion, and to play a part in forming attitudes, which affect morality. The Nigerian Television has not lagged behind in revitalizing the nation's cultural heritage and promoting the musical and dramatic talents.
In our efforts to promote indigenous culture, we should accentuate those things that bind us together as a nation and not those that tend to dichotomize us into fragmented states. The T.V. station must ensure that only the right virtues are transmitted to the viewers. For viewers, a station is justified by the quality of programmes that emanate therefrom. People are more interested in watching plays and drama, which deal directly with their culture. The keenness and alertness with which people watched the "Arelu" drama series of Jimoh Alliu in the early nineties on television will confirm this claim.

In spite of all these, the television medium has not been perfect and needs to guide against telecasting bizarre culture and social activities. African culture has been indicated in the past as being savage and ferocious. It should therefore ensure that barbaric entertainments are removed. The presence of too much Western culture in telecasts should also be checked, as it could lead to cultural imperialism rather than cultural transformation.

\section{THE ROLE OF RADIO}

Since independence, radio broadcast programmes have tried its best to live up to its objective of promoting cultural awareness throughout the Nigerian federation. Part of these objectives is to essentially cover the areas of aesthetics, religion, ethics, philosophy, language, history and arts.

In line with their objectives, radio programmes have tried as much as possible to be oriented towards:

(a) Seeking, identifying and preserving Nigerian culture and promoting the study of Nigerian history and language.

(b) Selecting critically, relevant foreign culture for the purpose of enriching Nigerian culture.

(c) Developing and promoting the appreciation of indigenous aesthetic values by citizens.

One of the objectives of the Federal Radio Corporation of Nigeria (FRCN), formerly known as the Nigerian Broadcasting Corporation (NBC) is to "provide a professional and comprehensive coverage of Nigerian culture through broadcasting; to promote cultural growth through research into indigenous cultures, and to disseminate the results of such research" (Onabajo, 2000: 14). 
The National Broadcasting Commission which was later set up by Decree 38 of 1992 as a regulating body for broadcasting in Nigeria was also given the duty of promoting Nigerian indigenous cultures, moral and community life through broadcasting.

The radio has been a very effective means of transmitting and promoting cultural, moral and community life most especially because of its unique characteristics. In most rural areas, the radio is the commonest mass medium that people can relate with intimately. It has been known as coming in handy anytime it is needed due to its easy mobility. Radio stations have therefore capitalized on this advantage to promote our cultural heritage.

According to Moemeka (2000:120), radio can be used in cultural innovation or diffusion. Since culture is not static, radio could help remove the negative aspects of some of our cultures and help the citizens to absorb that, which will improve their welfare and culture awareness. It could also be used to bring to children, youths and adults the greatest achievements of our cultural heritage in art, music, drama, poetry and so on.

\section{THE ROLE OF THE THEATRE}

In the early theatre days in Nigeria, drama and theatre were formidable socialisers. Many young undergraduates cultivated good and debonair manners as a result of these. The Nigerian theatre did not only have a rapport with politics and nationalism, it influenced political thoughts and identified with the external projection of the national image and our culture.

There has been in the last decade a right and proper emphasis on management in the Theatre Arts departments, an emphasis which one would like to see almost in the same proportion in the department of Fine Arts in the universities.

The production of two of Wole Soyinka's early plays by Geoffrey Axworthy and Ken Post in February 1959 (The Swamp Dwellers and The Lion and the Jewel) can be legitimately regarded as pathfinders in the journey towards our cultural nationhood and celebration of our culture (Ekeh, 1989: 62)

The theatre arts have many parts and all the parts in one way or the other have a role to play in the promotion of indigenous culture, morality and community life. In fact, the theatre is one of the major media that promotes our cultural heritage most. Most of the products of the theatre are culturally oriented and focus on our traditions - Dating back from the days of Hubert Ogunde to Wole Soyinka, the theatre has been a major force in the promotion of arts and culture.

The novel as part of the theatre art has had remarkable success with the large number of novels in English and Yoruba language, although one would like to see the emergence of a similar range of novels in other Nigerian indigenous languages.

Authors like Gabriel Okara, Wole Soyinka, Chinua Achebe and so on have successfully inputed the Nigerian culture into novels and educated people more on our unique culture. The Nigerian taste for novels is very high and one would like to see the emergence of more novelists both in the English language and in the large number of indigenous languages spoken by Nigerians.

Poetry is an essential part of our culture which has been made use of by men like Wole Soyinka to promote our culture; both oral and written poetries in English and indigenous languages. One of the oral indigenous poetry styles is the "ewi" in Yoruba land, which has had exposure both on T.V., radio and theatres and has also helped in promoting indigenous cultures.

Drama has raised a lot of interest in Nigeria and due to its effective ways of communicating and passing across moral values, cultures e.t.c. it has been a very useful medium used in theatre arts to promote indigenous cultures.

The role of the artist in contemporary Nigerian society is one that is of interest at the present time, not only to artists but also to the bigger Nigerian community who expect a great deal of productivity from the artists. Artists have the potential to transform the Nigerian society and promote indigenous cultures through songs of joy or sorrow, dances that delight, poems that teach and sculptures and paintings that excite the imagination.

As we move forward with confidence towards greater integration and national identity, we must continue to take pride in the unity in diversity of our heterogeneous national artistic kaleidoscope and seek meaningful ways of making it yield dividend for the glory of our land's culture and civilization (Ekeh, 1989: 81).

\section{THE ROLE OF COMMUNITY LEADERS}

Usman (1989: 69) identifies a traditional ruler 
as "the person who by virtue of ancestry occupies the throne or stool of an area and who has been appointed to it in accordance with the customs and traditions of such areas and whose throne has being in existence before the advent of the British in Nigeria."

Therefore, a traditional ruler in this context is the paramount authority or natural ruler in any given Nigerian community. However, their status varies from one community to another. Below the traditional rulers, there is another hierarchy of subordinate chiefs, appointed by them. They assist the traditional rulers in discharge of their duties.

These traditional/community leaders exercise legislative, judicial and executive functions even though they were curtailed during the colonial period.

The traditional leaders perform traditional roles and serve as fathers to their people.

The community leaders formulate general proposals on any aspects of the life of the community in their domains in the form of advise to local government. They also help give publicity to tax payable and help to collect the taxes (in some cases helping also in community tax assessment) (Usman, 1989:74).

One of the major roles they play is their support for Arts and Culture. Through this, our cultural heritage is being protected as these leaders fought for the promotion of our culture and warred against cultural imperialism.

These community leaders also determine customary laws and practice on all matters especially those relating to land, marriage and chieftaincy titles. Most of these laws are based on their indigenous culture, morals, values and community life.

They also deliberate on matters, which they consider important to the well being of their communities.

They also co-ordinate development plans of local governments through discussion and advice. In this way, they influence the local government in favour of the community life and culture of their people.

One obvious fact manifest since independence is that community leaders have always played the role of neutralizing crises as and when they arise. Besides, the government has realized that the surest way to win the hearts and minds of the citizens on major issues of the day is through these community leaders, though the government has denied these leaders any meaningful role in the governing of their people (Usman, 1989:83).

Whatever the basis, the survival of traditional leaders is significant because they provide the vital linkage between the government and the people; they influence the success of specific modernization schemes by serving as translators, interpreters and mediators of government goals (Usman, 1989: 85).

\section{THE WAY OUT}

For there to be adequate and meaningful promotion of our cultural heritage, the following issues have to be addressed:-

(i) Provision of basic infrastructural facilities necessary for the growth and development of the mass media to facilitate rapid and efficient dissemination of development information

(ii) Addressing the political and economic climates that have pervaded Nigeria in the past several years will help the mass media operate in a enhance conducive atmosphere to co-ordinate and efficient performance that will help achieve a self-sustaining development.

(iii) One of the most crucial factors of an orderly development process is education. It is essential to every aspect of mass communication, both the sender of the message and the receiver. Unless there is education, development may be an uphill task for the community, society or nation.

(iv) The aspect of technology development is also a very crucial aspect that has to be addressed before the media is able to promote our cultural heritage. Without the input of technology, there will be lack of quality in mass media products.

(v) The media should help promote indigenous cultures by being more culturally oriented in their programmes and products. They should help educate people more on their culture and how they can be imbibed, eliminating in the process undesirable negative cultural values.

(vi) Information to the people from the media should focus their attention on the need for change as well as the measures necessary for bringing about change; raise people's aspirations so that they can see change as very desirable. 
(vii) People should be allowed to participate intelligently and meaningfully in the decision process that will affect their lives, cultures and values.

\section{CONCLUSION}

The mass media should play the role of facilitating public debate, decision-making, and reaching public consensus on vital issues of public interest. Cultural redirection, information flow, education and culture, national development, political and social mobilization, entertainment and recreation are all numerous uses the media could be put to.

In strengthening the independence and selfreliance of the nation, it should be recognized that all individuals and people collectively have an inalienable right to a better life, which howsoever conceived, must ensure a social minimum. Since communication is interwoven with every aspect of life, the future of the mass media must be considered of utmost importance in the overall social, cultural, moral, economic goals of the nation.

In ensuring a bright future for our cultural heritage, we need a revolutionary Nigerian mass media, which can present and carry forward our revolutionary purpose of promoting our heritage.

We need a mass media to help create a feeling of nationhood among people traditionally divided by tribal loyalties; to explain the objectives of a new socialist society; to spread information about new and better ways of living; to win support for our country, its culture and its leadership and to motivate and mobilize the entire nation so as to realize its full potentials.

Whatever the pre-occupations of the Nigerian media, be they programmes in drama, sports, situation comedy, telefilm or news, they must continue to promote an integrative indigenous culture, moral and value system in our search for nationhood, identity and national prosperity.

\section{REFERENCES}

Akpan, E.D. 1988. "Television and National Security" in R. A..Akineleye (ed.) Contemporary Issues in Mass Media for Development and National Security. Lagos: Unimedia Publications Ltd.

Harunah, H. B. 2000. Nigeria Oral Traditions and Oral History. Lagos: Nigerian Association for Oral History and traditions

Moemeka, A. 2000. Development Communication in Action: Building Understandings and Creating Participation. Lanlian, Maryland: University Press of America Inc.

Nida, E. A. 1954. Customs and Culture. New York: Harper \& Raw Publishers.

Olaide, A. B. 2000. Badagry: The Cultural Heritage. Lagos: Asefada Ventures.

Onabajo, O. 2000. Fundamentals of Broadcast Journalism. Lagos: Gabi Concept Ltd.

Usman, Y. B. 1989. Nigeria Since Independence: The First 25 years. Ibadan: Heinemann Educational Books (Nigeria) Ltd.

Voelker, F. H. 1975. Mass Media: Forces in Our Society. Atlanta: Harcourt Brace Jovanovich Inc.

Warren, R.L. 1965. Studying Your Community. Toronto: Collier-Macmillan Press Ltd. 